\title{
Erratum: Growth suppression of four cancer cells by hyperbaric nitrous oxide and methotrexate (Korean J Anesthesiol 2010; 58(1): 61-69)
}

Cheol Hee Jung ${ }^{1}$, Ji Yeon Sim², and Wonsik $\mathrm{Ahn}^{1}$

Department of Anesthesiology and Pain Medicine, ${ }^{1}$ Seoul National University Hospital, ${ }^{2}$ College of Medicine, University of Ulsan, Seoul, Korea

The article by Jung $\mathrm{CH}$, et al. entitled, "Growth suppression of four cancer cells by hyperbaric nitrous oxide and methotrexate" (Korean J Anesthesiol 2010; 58(1): 61-69.) contained an error in Acknowledgements.

\section{The correct information is found below:}

This study was supported by grant no 800-2006-0234 from the SNUH Research Fund.

The authors apologize for any inconvenience this mistake may have caused.

\footnotetext{
Corresponding author: Wonsik Ahn, M.D., Department of Anesthesiology and Pain Medicine, Seoul National University Hospital, 28, Yeongeondong, Jongno-gu, Seoul 110-744, Korea. Tel: 82-2-2072-3087, Fax: 82-2-747-5639, E-mail: aws@snu.ac.kr

(c) This is an open-access article distributed under the terms of the Creative Commons Attribution Non-Commercial License (http:// creativecommons.org/licenses/by-nc/3.0/), which permits unrestricted non-commercial use, distribution, and reproduction in any medium, provided the original work is properly cited.
} 